http://kitaibelia.unideb.hu/

ISSN 2064-4507 (Online) • ISSN 1219-9672 (Print)

(C) Department of Botany, University of Debrecen, Hungary

23 (2): 170-178.; 2018

DOI: $10.17542 /$ kit.23.170

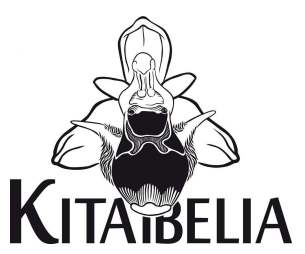

\title{
Újabb adat a hazai adventív flóra ismeretéhez: a Lactuca tatarica (L.) C.A. Mey. 1831 Magyarországon
}

\author{
Korda Márton*, KergyiK Éva, Tóth Anna \& CSISZÁr Ágnes
}

SOE Növénytani és Természetvédelmi Intézet, H-9400 Sopron, Bajcsy-Zsilinszky utca 4.; *korda.marton@gmail.com

\section{Lactuca tatarica (Asteraceae), a new species for the Hungarian alien flora}

\begin{abstract}
The first occurrence of blue lettuce (Lactuca tatarica (L.) C.A. Mey.) is reported from Hungary. Information on its taxonomy, morphology, distribution, habitat preference and nature conservation aspects is presented. The European local spread of this Eurasian and North American species started at the end of the 1800s. The first localities were reported from the shores of the Baltic and North Sea. Its alien occurrences in inland European regions have been noticed since the 1920s. As L. tatarica have previously been known from the neighbouring territories of Slovakia and Austria, its appearance in Hungary is not at all unexpected. However, the species was found (August 2018) in the southern part of Csongrád county, i.e. far away from the above-mentioned countries. Due to the species' habitat preference (ruderal ground), ecological requirements and successful vegetative propagation, which correspond to foreign observations, its future spread is highly probable.
\end{abstract}

Keywords: Asteraceae, biological invasion, blue lettuce, Danube-Tisza Interfluve

Összefoglalás - A szerzők beszámolnak az eurázsiai és észak-amerikai elterjedésű tatár saláta (Lactuca tatarica (L.) C.A. Mey.) első magyarországi előfordulásáról. Ismertetik a faj fontosabb taxonómiai, morfológiai, chorológiai, élőhelyi sajátosságait, illetve a természetvédelmi vonatkozásait. Őshonos elterjedési területén kívüli európai terjedése az 1800-as évek végén vette kezdetét. Az első jelentősebb adatok a Balti-, illetve az Északi-tenger partvidékéről származnak. Az 1920-as évektől Európa számos, a tengerektől távol eső pontján is megfigyelték jövevény fajként. Mivel előfordulása Szlovákia és Ausztria Magyarországhoz közeli területein évtizedek óta ismert, hazai előkerülése nem váratlan. Meglepő módon azonban nem az említett országokhoz közel, hanem Csongrád megye déli részén került elő 2018 augusztusában. A szomszédos országokhoz hasonlóan hazánkban is jellegtelen, bolygatott élőhelyen telepedett meg. A faj ökológiai igényeit, agresszív vegetatív terjedőképességét, illetve a külföldi tapasztalatokat figyelembe véve további terjedése várható.

Kulcsszavak: Asteraceae, biológiai invázió, Duna-Tisza köze, tatár saláta

\section{Bevezetés}

Cikkünkben az eurázsiai és észak-amerikai elterjedésű tatár saláta (Lactuca tatarica (L.) C.A. Mey.) első magyarországi előfordulását, és ennek kapcsán morfológiai, élőhelyi és taxonómiai sajátosságait, illetve természetvédelmi vonatkozásait ismertetjük. Mivel a faj Szlovákia és Ausztria Magyarországhoz közeli területein évtizedek óta jelen van, ezért hazai előkerülése nem váratlan, ennek valószínűségére Terpó András már 1999-ben felhívta a figyelmet (LőKös 1999-2000). A várakozásokkal ellentétben azonban a faj nem az említett két országgal szomszédos területekről, hanem Csongrád megye déli részéről került elő 2018. augusztus 4-én. 


\section{Nevezéktan, taxonómia}

A fajt 1771-ben Linné írta le Sonchus tataricus L. néven (LinNé 1771). Az azóta számos nemzetségbe átsorolt és számos szinonimmal leírt faj ma elfogadott tudományos nevét MEYER (1831) publikálta: Lactuca tatarica (L.) C.A. Mey., Verz. Pfl. Cauc. 56 (1831). SoJÁK (1961) külön nemzetségbe sorolta Lagedium néven, de ez a felfogás kevésbé vert gyökeret a taxonómiai munkákban. Ezzel szemben gyakran olvashatjuk említését a Mulgedium nemzetségből, melyet ma jellemzően a Lactuca nemzetség alnemzetségének (KNAPP \& JAGE 1978, TZVELEV 2003), vagy szekciójának (TuTin et al. 1976) tartanak. KNAPP \& JAGE (1978) a Mulgedium alnemzetség típusfajaként tárgyalja.

A The Plant List adatbázisa szerint (RBG 2018) a fajt az alábbi szinonimokon említik: Agathyrsus pulchellus D.Don 1829, A. tataricus (L.) D.Don 1829, Cicerbita tatarica (L.) Sosn. 1945, Crepis charbonnelii H.Lév. 1913, Galathenium integrifolium (Bigelow) Nutt. 1841, Lactuca clarkei Hook.f. 1881, L. integrifolia Nutt. 1818, L. multipes H.Lév. \& Vaniot 1909, L. oblongifolia Nutt., L. pulchella (Pursh) DC. 1838, L. sylvatica A.Nelson 1899, Lagedium tataricum (L.) Soják 1961, Mulgedium heterophyllum Nutt. 1841, M. oblongifolium (Nutt.) Reveal 2007, M. pulchellum (Pursh) G.Don 1839, M. roborovskii Tzvelev 2007, M. runcinatum Cass. 1824, M. tataricum (L.) DC. 1838, Sonchus lactucoides Bunge 1833, S. pulchellus Pursh, $S$. sibiricus Richardson 1823, S tataricus L. 1771, S. volhynicus Besser ex Nyman 1879, Wiestia tatarica (L.) Sch.Bip. 1841.

PRISZTER (1998) a növényneveket tárgyaló kötetében a fajt a tatár saláta magyar névvel illeti.

A Lactuca nemzetségből hazánkban ez idáig hét fajt jeleztek, melyből öt őshonos. A további kettő a L. sativa L., melyet széles körben termesztenek, illetve a mediterrán elterjedésű L. virosa L. melynek egykori adventív előfordulása Pestről ismert (PENKSZA \& SzERDAHELYI 2009). Az utóbbi két fajt BALOGH et al. (2004) az alkalmilag elvaduló fajok között említi.

\section{Morfológiai jellemzés}

Az alaktani jellemzés a hazánkban talált példányok leírásán túl HEGI (1928), NYÁRÁDY (1965), TUtin et al. (1976), OBERDORFER (1983), FisCHER (2005), BojNANSKÝ \& FARGAŠOvÁ (2007), CIOCÂRLAN (2009) és BANO \& QAISER (2011) munkáinak felhasználásával készült.

A Lactuca tatarica 30-80(-150) cm magas, a felső részében elágazó, felálló szárú, szaporítógyökeres $\left(\mathrm{G}_{3}\right)$ évelő. A gyökérzete mélyre hatoló, a szaporítógyökerek a felszín alatt többé-kevésbé vízszintesen futnak. A szár és a levelek szürkészöldek, elszórtan szőrösek, vagy teljesen kopaszak. Levelei lándzsásak vagy hosszúkásak, tagoltságuk rendkívül változatos, a tagolatlantól az osztottig változhat. Jellemzően az alsó levelek kacúrosak, hasadtak vagy osztottak, széles háromszög alakú tagolatokkal, míg a felsők tagolatlanok. A tagolt és tagolatlan levelek között fokozatos az átmenet. Előfordul, hogy csak a legalsó levelek tagoltak, melyek a virágzásra már elszáradnak, így látszólag csak tagolatlan levelei vannak. A levél csúcsa hegyes, az alsó levelek gyakran rövid nyelűek, kissé nyélbekeskenyedők, míg a felsőbbek ülők. Szélük finoman, szabálytalanul fogazott, vagy teljesen ép. A hazai példányokon mért adatok alapján a levél 5,3-16 cm hosszú, és 1-4 cm széles (a levél közepénél mérve). Virágai kékek vagy lilák, igen ritkán fehérek. A fészekben 16-23 virág található. A fészkek sok virágzatból felépülő bugában állnak. A külső fészekpikkely tojásdad, hegyes, míg a belső hosszúkás és tompás. FISCHER (2005) a L. perennis L.-től való elkülönítésre határozóbélyegként emeli ki, hogy a fészekpikkelyek 15-18 mm hosszúak, míg ez az adat a L. perennis esetében csak 10$15 \mathrm{~mm}$. A hazai példányokon mért adatok ezt a bélyeget nem támasztják alá, a leghosszabb fészekpikkelyek hossza is csak 10-14 mm között változott. A fészekpikkelyek zöldek, szélü- 
kön fehér sávval, a felső részük eltérő mértékben pirosas. Júliustól augusztusig virágzik. Kaszattermése hosszúkás elliptikus, a csúcsi részénél hosszan elkeskenyedő (4,5-6,5 × 0,9-1,1 $\mathrm{mm}$ ), lapított, hosszanti irányban számos feltűnő bordával barázdált. A kaszat csőre jóval rövidebb, mint a teste, kb. $1 \mathrm{~mm}$ hosszú. A színe sárgásbarnától feketéig változhat, finoman elszórtan szőrözött vagy kopaszodó. Bóbitája fehér, kb. kétszer hosszabb, mint a kaszat. A faj fontosabb morfológiai bélyegeit az 1. ábra mutatja.

A közép-európai tapasztalatok alapján a L. tatarica újabb előfordulásaira minden bizonynyal számíthatunk hazánkban is, így az alábbiak szerint indokolt a hazai Lactucahatározókulcsba (PENKSZA \& SzERDAHELYI 2009) való illesztése.

1a $A$ virágok kékek v. kékeslilák 2

1b A virágok sárgák 3

2a A kaszat 1-3 bordájú. A levél szárnyasan osztott, lándzsás v. szálas osztatokkal. Vízszintesen futó szaporítógyökerek nincsenek. - A levél szürkészöld. A fészek 12-20 virágú. A kaszat 10-14 mm hosszú, a csőre majdnem olyan hosszú, mint a teste. T: (20-)30-80 cm. He. V-VI. Sziklagyepek. K szórv., NyDt (Soproni-dv.) †?, DDt (Villányi-hg.)?

L. perennis L. - Kék s.

2b A kaszat több bordájú. A levél tagoltsága a tagolatlantól az osztottig változhat, széles háromszögű osztatokkal. Vízszintesen futó szaporítógyökerek vannak. - A levél szürkészöld. A fészek 16-23 virágú. A kaszat 4,5-6,5 mm hosszú, csúcsi részénél hosszan elkeskenyedő, a csőre jóval rövidebb, mint a teste. T: 30-80(-150) cm. Ge. VII-VIII. Ruderális gyomtársulások. NA (D-T: Szatymaz) igen ritka.

L. tatarica (L.) C.A. Mey. - Tatár s.

\section{Elterjedési terület}

A faj őshonos areája lefedi Észak-Amerikát és Eurázsia kontinentális területeinek nagyrészét (LEBEDA et al. 2004, CIOCÂRLAN 2009, KARTESZ 2018). Őshonos elterjedési területe magába foglalja az Amerikai Egyesült Államok és Kanada nagyrészét; Ázsiában lefedi a Kaukázust, az Iráni-fennsíkot, Szibéria nyugati, keleti és déli részét a Lénáig, Közép-Ázsiát, valamint Kínát és Tibetet. Az area ázsiai részével összefüggően Kelet-, illetve Délkelet-Európába is átnyúlik, nyugatra a Fekete-tenger partvidékéig, érintve Oroszország és Törökország európai részét, Romániát, Bulgáriát és Ukrajnát (HEGI 1928, NYÁRÁDY 1965, TUTIN et al. 1976, FERÁKOVÁ 1977, JEHLík 1980, TzVELEV 2003, CiOCÂRLAN 2009, KoWALSKI et al. 2015, KARTESZ 2018).

Adventív flóraelemként Európa számos további területéről ismert, terjedése jól dokumentált. Első szubspontán adata Nagy-Britanniából vált ismerté 1884-ben a Stour folyó partjáról, de a századfordulón (1902-ben) már a kontinensen is gyüjtötték a Balti-tenger német partján, Elő-Pomerániában (RoTHMALER et al. 1986, CASTRI et al. 1990). 1975-re a Balti-tenger minden part menti országában megjelent: Svédország (1915), Finnország (1922), Lettország (1926), Dánia (1926), Észtország (1950-es évek), Lengyelország (1957), Litvánia (1975) (HEGi 1928, KovANDA 1958, TuTin et al. 1976, KNAPP \& JAGE 1978, WAGENiTz 1987). A térségben tapasztalt terjedésének ütemét jól példázzák a német adatok. RoTHMALER (1956) még csak Mecklenburgból említi, ROTHMALER et al. (1984) és OBERDORFER (1994) már öt tartományból jelzi, míg BETTINGER et al. (2013) térképe már hat tartomány érintettségét mutatja. OBERDORFER (1983) már meghonosodottként tárgyalja. 


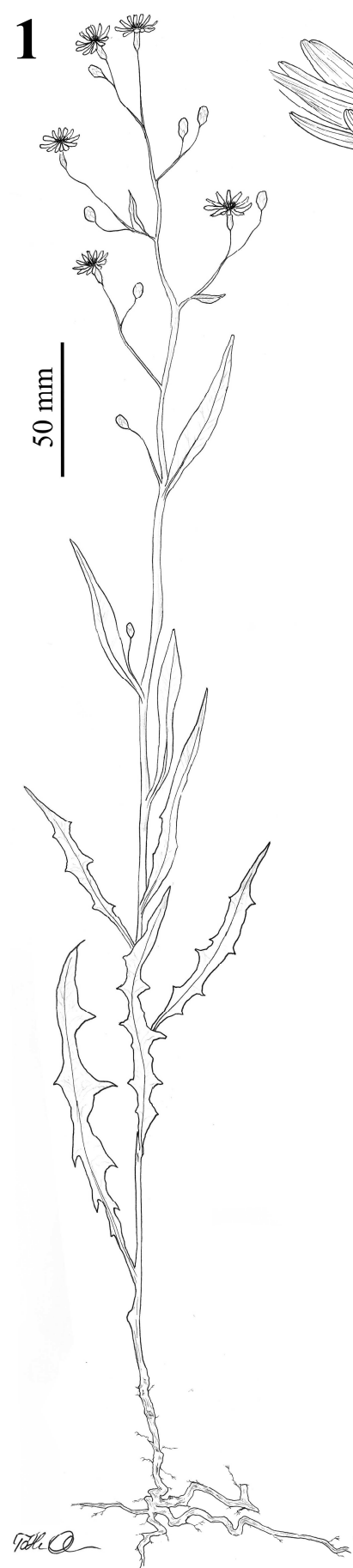

3
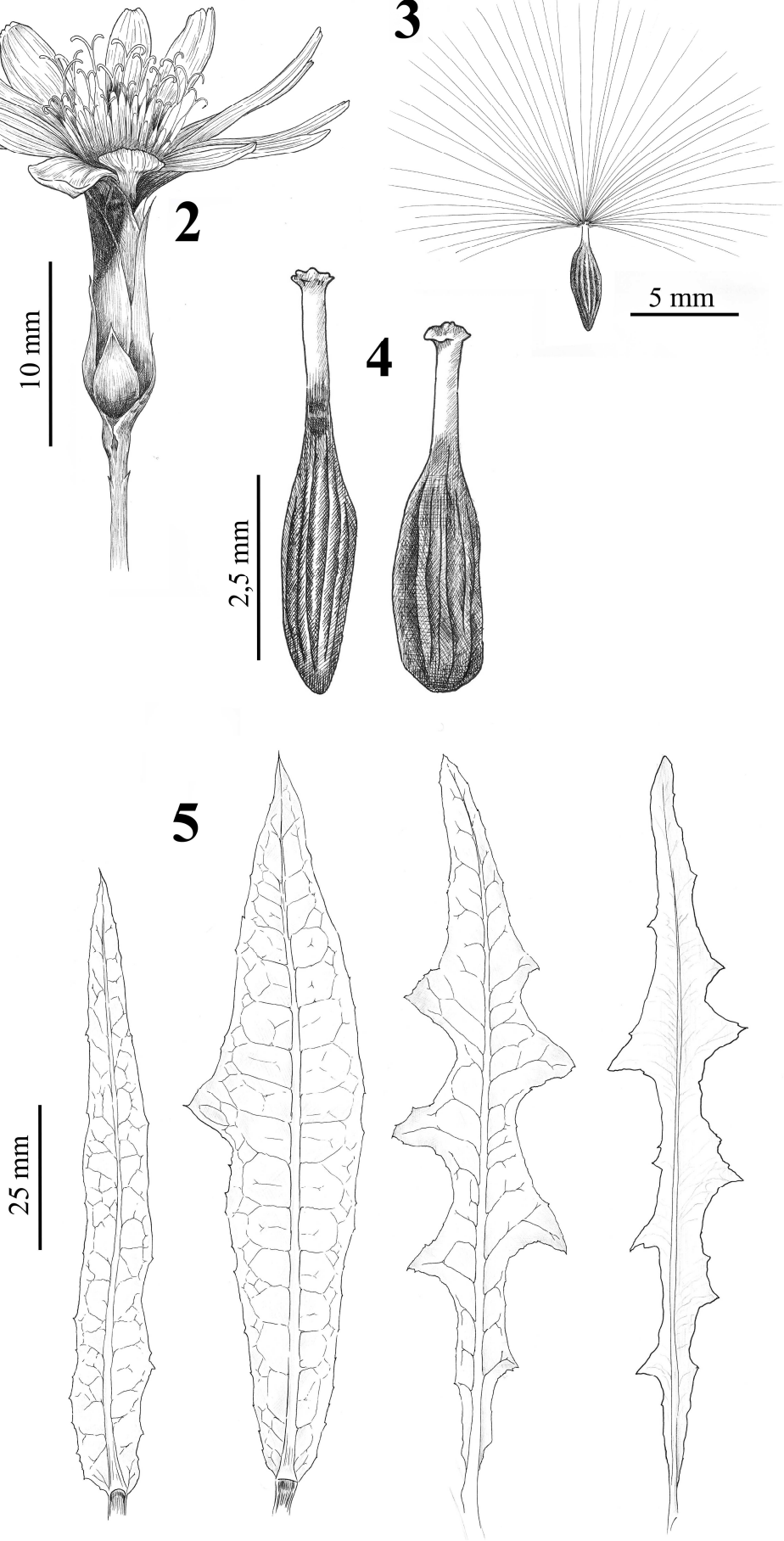

1. ábra. Lactuca tatarica. 1: habitus, 2: virágzat, 3: kaszat bóbitával, 4: kaszat, 5: levelek (Tóth Anna eredeti rajza)

Fig. 1. Lactuca tatarica. 1: habit, 2: inflorescence, 3: cypsela with pappus, 4: cypsela, 5: leaves (original drawn by Anna Tóth) 
Az 1940-es évektől az Északi-tenger partjainál is hasonló folyamatok indultak el. Előkerült Hollandiából (1942), Németországból (1947), és Norvégiából, továbbá észlelték Írországban is (HEGi 1928, TuTin et al. 1976, KNAPP \& JAGE 1978, WAGENITZ 1987, TZvELEV 2003). KNAPP \& JAGE (1978) a térségre vonatkozóan konkrét állományadatokat is közöl. A németországi Emden kikötőjében 1947-ben kb. 100 tövet számoltak, míg egy évvel később már 300400-at. Egy holland szigeten 1967-ben 200 tövet becsültek, míg 1974-ben már 1700-at.

A tengerparti területek meghódítása mellett Közép-Európa belső, a tengerektől távol eső részein is terjedni kezdett. Az első adata 1920-ból Berlinből származik, illetve két évvel később a szász-anhalti Köthenből is előkerült (HEGI 1928). 1957-ben megtalálták az akkori Csehszlovákiában Prága mellett, majd 1962-ben már a Kárpát-medencében, a ma Szlovákiához tartozó Tiszacsernyő (Čierna nad Tisou) teherpályaudvarán is (KNAPP \& JAGE 1978). 1978-ban Csehszlovákiában 9 előfordulása volt ismert, de JeHLík (1980) már 14 helyről említi, és a faj meghonosodásáról tudósít. 1978-ban Lengyelország tengertől távoli területén két helyről volt adata (KNAPP \& JAGE 1978, PYŠEK et al. 2002). Ausztriában 1988-ban jelent meg a Bécsi-medencében (Melzer 1990), de az osztrák előfordulásokat Fischer (2005) instabil állományokként értékeli, melyek hosszabb távon nem tudnak meghonosodni.

A fentiek mellett adventív megjelenését jelzik Oroszország európai részének azon területeiről is, melyeken őshonosan nem fordult elő (Tzvelev 2003), míg TuTiN et al. (1976) svájci jelenlétét is említi.

KNAPP \& JAGE (1978) a 20. század elejétől tapasztalható terjedést két párhuzamos folyamatként értékeli. Megítélésük szerint az Északi- és Balti-tenger partjain kialakuló diszjunkt arearész főként természetes folyamatoknak köszönhető. Ezzel szemben a kontinens belső területein való megjelenése kétséget kizáróan antropogén hatások eredménye.

A behurcolás mikéntjére számos magyarázat született. Az adventív előfordulások között feltűnően sok a vasútállomás, így kézenfekvő, hogy a vasút alapvető szerepet játszik a faj terjesztésében, de emellett a vízi közlekedéssel, a háborús csapatmozgásokkal, a vetőmag-, illetve takarmánykereskedéssel, sőt a Balti-tenger régiójában a talpastyúk (Syrrhaptes paradoxus Pall.) 1880-as években tapasztalt inváziójával is összefüggésbe hozzák (KNAPP \& JAGE 1978, JEHLíK 1980). Ez utóbbi feltevés kapcsán azonban WAGENITZ (1987) megjegyzi, hogy egyre kevesebben tartják valószínűnek.

\section{Termőhelyi viszonyok}

KNAPP \& JAGE (1978) összefoglalja a faj fontosabb ökológiai igényeit. Ez alapján egy erősen fényigényes, pionír jellegű (vegetatív úton kolonizáló pionír), kontinentális fajról van szó, mely minden más tulajdonságát tekintve tágtűrésű. A relatív hőmérséklet számára indifferens, erősen szárazságtűrő, de a mérsékelten nedves termőhelyeken is megél, a mérsékelten szikes talajokat sem kerüli, és a tápanyagban szegény, illetve abban gazdag termőhelyeket egyaránt képes hasznosítani. Előfordulása az alföldtől egészen 2500-5000 m tengerszint feletti magasságig ismert. Mindezek ismeretében nem meglepő, hogy számos termő-, illetve élőhelyen előfordul.

Alapvetően tipikus sztyeppnövénynek tartják. Természetes areájának súlypontja erdőssztyeppi, sztyeppi és félsivatagi területeket fed le (HEGI 1928). TuZSON $(1911,1914)$ a dél orosz sztyeppék (szikesek is) jellemző fajának tartja és a Fekete-tenger mentén a sztyepp és a meder közti lazatalajú lejtők jellemző növényei között említi. TzvELEV (2003) szolonyec és szoloncsák talajokról egyaránt jelzi.

A faj pionír jellege legszembetűnőbben a tengerparti előfordulások esetében mutatkozik meg. A tengerparti nyílt homokon, illetve homokdûnéken elterjedt faj, de tavak, csatornák és folyók mentén, kavicszátonyokon, folyó menti cserjésekben is előfordul (NYÁRÁDY 1965, 
Tutin et al. 1976, KNAPP \& JAGe 1978, Rothmaler et al. 1984, Tzvelev 2003, CiocÂrlan 2009, KOWALSKI et al. 2015). KNAPP \& JAGE (1978) arról is beszámol, hogy a természetes areán belüli Tatárföldön széles körben elterjedt szántóföldi gyommá vált.

A másodlagos elterjedési területe látványos kettősséget mutat. A tengerparti területeken az őshonos areájához hasonló élőhelyeket kolonizál, tehát a természetes vegetációban terjed. Ezzel szemben a kontinens belső területein gyom jellegű fajként viselkedik, kizárólag erősen bolygatott, ruderális termőhelyeken jelenik meg. Adatai települési környezetből (pl. vasút és út mente), szeméttelepről, külszíni bányákból, szántóföldekről, kertekből, parlagokból, tűzvédelmi pásztákból származnak (TUTIN et al. 1976, KNAPP \& JAGE 1978, OBERDORFER 1983, ROTHMALER et al. 1984, TZVELEV 2003, FISCHER 2005, KOWALSKI et al. 2015)

\section{Magyarországi előfordulás}

A Lactuca tatarica állománya 2018. augusztus 4-én került elő a Dél-Tisza-völgyi Szatymazon, a Szegedi Fehér-tó északnyugati sarkánál, a tavat nyugatról övező csatorna és a szántóföldek közötti gyér ezüstfás (Elaeagnus angustifolia L.) sáv mellett haladó földút menti mezsgyéből (KEF-kvadrátazonosító: 9686/3), szikes talajon (2. ábra). Az élőhely egy Elymus repens (L.) Gould által uralt jellegtelen, gyomos gyep (a L. tatarica közvetlen közelében előforduló további fajok: Poa angustifolia L., Dactylis glomerata L., Daucus carota L., Melilotus albus Desr., Sonchus arvensis L., Calamagrostis epigeios (L.) Roth, Asclepias syriaca L., Cichorium intybus L., Lotus corniculatus L., Inula britannica L., Odontites vernus (Bellardi) Dumort., Erigeron annuus (L.) Pers.). Körülbelül egy $30 \mathrm{~m}^{2}$-es területen virágzó, terméses és vegetatív állapotú egyedek fordultak elő, változó sűrűségű foltokban. A szomszédos szántóról ottjártunkkor a haszonnövényt már betakarították, a terület frissen volt szántva, a L. tatarica-t nem találtuk meg rajta. A növény bekerülésének konkrét magyarázatát nem ismerjük, de az előkerülés körülményei a vetőmaggal történt behurcolást valószínúsítik.

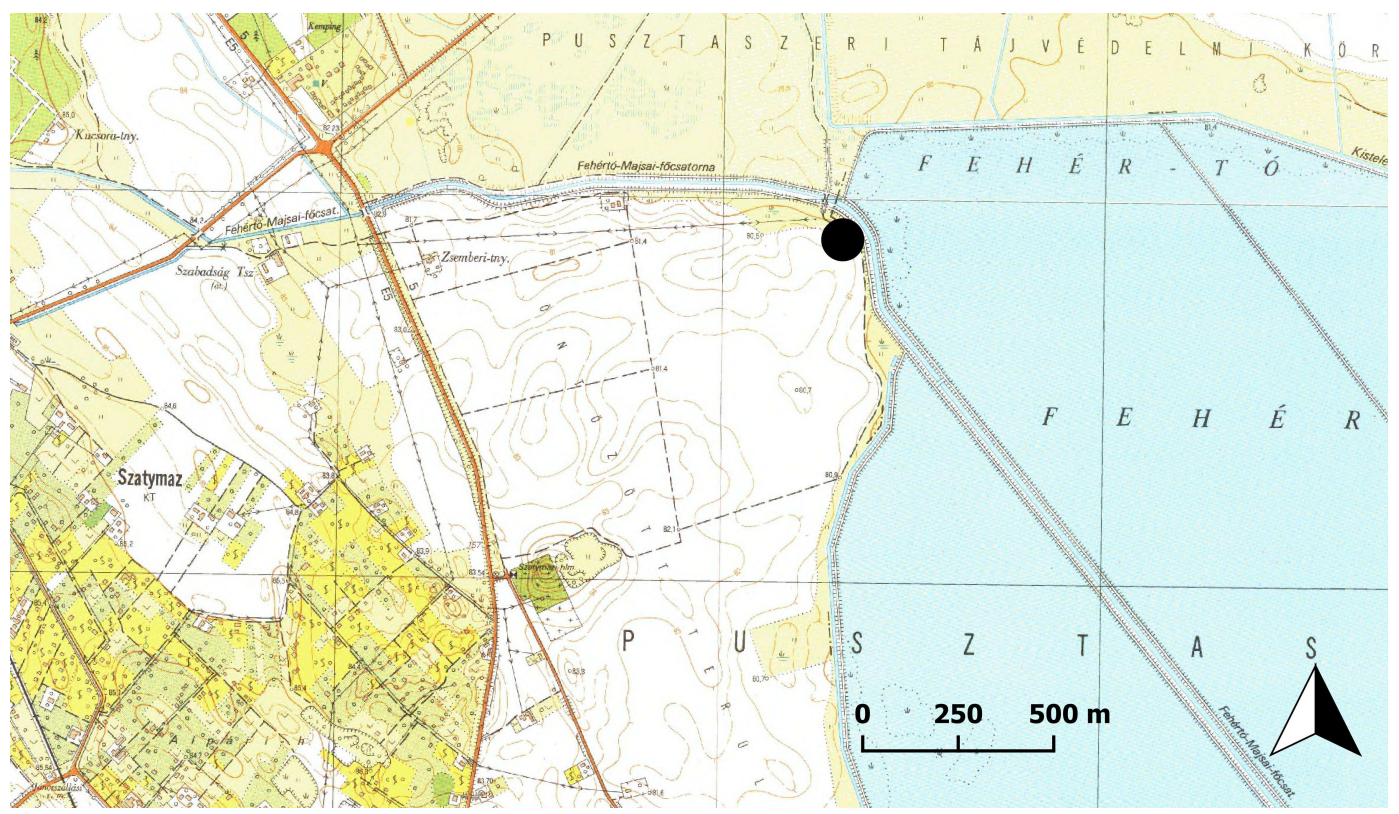

2. ábra. A Lactuca tatarica lelőhelye Szatymaz mellett (Csongrád megye)

Fig. 2. Locality of Lactuca tatarica near Szatymaz village (Csongrád county, S Hungary) 
A növényből gyűjtött bizonyítópéldány a Magyar Természettudományi Múzeum Növénytárában (BP) került elhelyezésre.

A hazai vonatkozások kapcsán említést érdemel JEHLík (1980) - fentebb tárgyalt - 1962es tiszacsernyői (ma Szlovákia) adata. Cikkéből azt is tudjuk, hogy a fajt az 1970-es évek végéig rendszeresen gyűjtötték itt. A szóban forgó pályaudvar a jelenlegi határainktól légvonalban kb. 3,5 km-re fekszik, így Borsod-Abaúj-Zemplén, illetve Szabolcs-Szatmár-Bereg megyék érintett térségében is érdemes volna a fajt keresni, annál is inkább, mert a gyakori ruderális termőhelyek mellett, a Tisza mentén a faj által ugyancsak preferált folyó menti pionír élőhelyek is jellemzők.

\section{Invázióbiológiai és természetvédelmi vonatkozások}

Ha csak a tatár saláta fentebb tárgyalt ökológiai igényeit vesszük figyelembe, már akkor is kijelenthető, hogy a nyílt élőhelyeken potenciálisan inváziós fajjá válhat. Mindemellett az inváziós sikeresség kérdésének tárgyalásánál nem tekinthetünk el a szaporodásbiológiai tulajdonságoktól sem. A témával többen is foglalkoztak, így némi rálátást nyerhetünk arra, hogy mekkora kockázatot jelent a faj megjelenése természetvédelmi és gazdasági szempontból.

A faj generatív szaporodásával kapcsolatban jelentős eltérések tapasztalhatók az őshonos, illetve a másodlagos elterjedési területén. JEHLík (1980) orosz tapasztalatokra hivatkozva az őshonos előfordulási területen magas magprodukcióról számol be. E szerint egyetlen növény 4000-5000 kaszatot is érlelhet, melyek csírázási erélye magas és 3-4 évig megőrzik csírázóképességüket. Ezzel szemben MELzer (1990) egy pomerániai vizsgálat kapcsán arról számol be, hogy a tengerparton előforduló egyedek által hozott terméseknek csak 10-20\%-a csírázott ki. Hasonló tapasztalatokról számol be Finnországra vonatkozóan is, ahol a faj csak nagyon ritkán hoz csírázóképes magot. Beszámol egy olyan esetről is, amikor egy kutató 20 virágzatból mindössze egyetlen kaszat kialakulását figyelte meg, míg a fehér virágú egyedek esetében a megvizsgált 2000 fészekben egyetlen termés sem fejlődött. JEHLIK (1980) az egykori Csehszlovákiából közöl hasonló megfigyeléseket, mely szerint a léha magok kialakulása gyakori.

A hazánkban előkerült állomány esetén is szembetűnő volt, hogy a fészkek többségében a kaszatok nem fejlődtek ki teljesen, léhák voltak. A kifejlődött kaszatok aránya helyszíni számlálás szerint $10-50 \%$ között változott.

A generatívval szemben, vegetatív szaporodásának hatékonyságát több szerző is igazolja. MELzER (1990) egy vegetatív szaporodási kísérletről számol be. Ebben az esetben egy fehér virágú egyed szaporítógyökerének egy kissé már fonnyadó, ujjnyi darabját kerti talajba helyezték, ahol a következő évben, egy $3 \mathrm{~m}^{2}$-es területen 76 hajtás fejlődését figyelték meg. Hozzáfúzi azt is, hogy minden bizonnyal a lila virágú egyedek is hasonlóan viselkednek. JEHLíK (1980) ugyancsak a sikeres vegetatív szaporodására hívja fel a figyelmet, megjegyezve, hogy gyökérzetének a felépítése a Cirsium arvense (L.) Scop. gyökérrendszerére emlékeztet, vagyis a folyamatosan fejlődő horizontális szaporítógyökereken sorra jelennek meg a hajtások, nagy polikormont alkotva. KNAPP \& JAGE (1978) adatai szerint az elsőéves egyed kb. $1 \mathrm{~m}$ hosszú gyökérrendszert tud létrehozni, míg a többéveseknél ez már 4-5 m-esre is fejlődhet. Megfigyeléseik szerint egy vegetációs periódus alatt egy egyed kb. 50 hajtást fejleszt.

A fentebb tárgyalt ökológiai igények, az agresszív vegetatív terjedőképesség, és az európai példák összességében előrevetítik a faj további terjedését. Igaz, hogy a csírázóképes magok viszonylag alacsony aránya korlátozhatja a robbanásszerü terjedést, de a roppant sikeres vegetatív szaporodás garantálja, hogy ha egy területen megtelepedett, akkor ott jelentős terjeszkedésnek indulhat. A faj adventív megjelenésével érintett tengertől távoli területeken kivétel nélkül ruderális élőhelyek, illetve szántóföldi kultúrák gyomnövényeként említik. 
Hazánkban azonban számolni kell azzal is, hogy a faj természetes areáján belüli fő élőhelyei közül a sztyeppi növényközösségekhez meglehetősen hasonló élőhelyeket találunk. Ez felveti annak a potenciális lehetőségét, hogy a tatár saláta nem „csak” egy kellemetlen ruderális gyomként jelentkezik, hanem mint a pannon biogeográfiai régió kimagasló jelentőségű természeti értékeit veszélyeztető inváziós növény.

A kérdés természetvédelmi vonatkozásokon túl, mint gyomnövény gazdasági problémákat is felvet. Erre utal az 58/1996. (IV. 17.) Korm. rendelet, mely Magyarország és Szlovákia közötti növényvédelmi együttmüködésről szól. Ennek értelmében a faj Szlovákiában karantén növénynek számít, melyet, ha vetőmagszállítmányban kimutatnak, akkor azt nem lehet az országba beszállítani. Az egyezmény egyébként azt is kimondja, hogy „a karantén károsítók előfordulásáról, valamint az azok elterjedésének megelőzése és felszámolása érdekében tett intézkedésekről haladéktalanul tájékoztatják egymást" a felek. Érdekesség ezzel kapcsolatban, hogy már JEHLík (1980) is javasolta, hogy kerüljön fel Csehszlovákia karantén listájára.

A fentiek fényében tehát mind természetvédelmi, mind gazdasági szempontból határozottan indokolt volna a faj hazai, jelenleg még kis kiterjedésű állományának a mihamarabbi felszámolása. Indokolt volna továbbá a környék fokozott monitorozása is az esetlegesen megjelenő új tövek felderítése és irtása céljából.

\section{Köszönetnyilvánítás}

Köszönettel tartozunk Barina Zoltánnak a vonatkozó irodalmak összegyüjtésében nyújtott segítségéért, és Winkler Dánielnek az ábrák technikai szerkesztéséért. A kézirat gondos lektorálásáért és a jobbító javaslatokért Csathó András Istvánnak és Jakab Gusztávnak mondunk köszönetet. A kutatást a VKSZ_12-1-2013-0034 „Agrárklíma 2” projekt támogatta.

\section{Irodalom}

BALOGH L., DANCZA I. \& KiRÁLY G. (2004): A magyarországi neofitonok időszerű jegyzéke és besorolásuk inváziós szempontból. - In: MinÁLY B. \& BoTTA-DuKÁT Z. (szerk.), Biológiai inváziók Magyarországon. Özönnövények. TermészetBÚVÁR Alapítvány Kiadó, Budapest, pp. 61-92.

BANo R. \& QAISER M. (2011): A Taxonomic Revision of the Genus Lactuca L. (Cichorieae- Asteraceae) from Pakistan and Kashmir. - Pakistan Journal of Botany 43 (5): 2259-2268.

Bettinger A., Buttler K.P., CaSPari S., KlotZ J., May R. \& Metzing D. (2013): Verbreitungsatlas der Farnund Blütenpflanzen Deutschlands. - Netzwerk Phytodiversität Deutschlands e.V. und dem Bundesamt für Naturschutz, Bonn - Bad Godesberg, 912 pp.

BojnANSKÝ V. \& FARGAŠOVÁ A. (2007): Atlas of Seeds and Fruits of Central and East-European Flora. The Carpathian Mountains Region. - Springer, Dordrecht, 1046 pp.

CiocÂRlan V. (2009): Flora ilustrată a României. Pteridophyta et Spermatophyta. - Editura Ceres, București, $1141 \mathrm{pp}$.

Di CASTRI F., HAnsen A.J. \& Debussche M. (1990): Biological Invasions in Europe and the Mediterranean Basin. - Kluwer Academic Publishers, Dordrecht/Boston/London, 463 pp.

FERÁKovÁ V. (1977): The Genus Lactuca L. in Europe. - Univerzita Komenského, Bratislava, 122 pp.

Fischer M.A. (ed.) (2005): Exkursionsflora für Österreich, Lichtenstein und Südtirol. - Land Oberösterreich, OÖ Landesmuseen, Linz, 1380 pp.

HEGI G. (1928): Illustrierte Flora von Mittel-Europa, VI. Band. 2. Hälfte. Dicotyledones (V. Teil). - J. F. Lehmanns, München, pp. 549-1386.

JeHLík V. (1980): Die Verbreitung von Lactuca tatarica in der Tschechoslowakei und Bemerkungen zu ihrem Vorkommen. - Preslia 52: 209-216.

Kartesz J.T. (2018): The Biota of North America Program (BONAP). North American Plant Atlas. (http://bonap.net/napa). Chapel Hill, N.C. [maps generated from Kartesz, J.T. 2015. Floristic 
Synthesis of North America, Version 1.0. Biota of North America Program (BONAP). (hozzáférés / accessed: 2018. 08. 20.)

KNAPP H.D. \& JAGE H. (1978): Zur Ausbreitungsgeschichte von Lactuca tatarica (L.) C. A. Meyer in Mitteleuropa. - Feddes Repertorium 89 (7-8): 453-474.

Kovanda M. (2004): Lactuca tatarica (L.) C. A. Meyer na Pomorzu Zachodnim - Lactuca tatarica (L.) C. A. Meyer found in Polish Pomerania. - Fragmenta Floristica et Geobotanica 4 (1-2): 129-131.

KoWALSKI W., ŁYSKO A. \& Popiela A. (2015): Lactuca tatarica (Asteraceae) in embryonic dunes on Wolin Island (NW Poland). - Biodiversity Research and Conservation 39: 61-66.

Lebeda A., Delezolová I., FeráKovÁ V. \& Astley D. (2004): Geographical Distribution of Wild Lactuca Species (Asteraceae, Lactuceae). - The Botanical Review 70 (3): 328-356.

LinNÉ C. (1771): Mantissa plantarum Altaera generum editionis VI. \& Specierum editionis II. - Impensis Laurentii Salvii, Holmiae, 587 pp.

LőKös L. (1999-2000): A Magyar Biológiai Társaság Botanikai Szakosztályának ülései (1999. február2000. december). - Botanikai Közlemények 86-87 (1-2): 229-267.

Melzer H. (1990): Lactuca tatarica (L.) C. A. Meyer, der Tataren-Milchlattich - ein Neophyt der österreichischen Flora? - Verhandlungen der Zoologisch-Botanischen Gesellschaft in Österreich 127: 155-159.

MEYer C.A. (1831): Verzeichniss der Pflanzen welche während der, auf allerhöchsten Befehl, in den Jahren 1829 und 1830 unternommenen Reise im Caucasus und in den Provinzen am westlichen Ufer des Caspischen Meeres gefunden und eingesammelt worden sind. - Kaiserliche Academie der Wissenschaften, St. Petersburg, $241 \mathrm{pp}$.

NYÁRÁdy E.I. (ed.) (1965): Flora Republicii Populare Romîne. X. - Editura Academiei Republicii Populare Romîne, București, 751 pp.

OBERDORFER E. (1983): Pflanzensoziologische Exkursions Flora. - Verlag Eugen Ulmer, Stuttgart, 1051 pp.

OBERDorfer E. (1994): Pflanzensoziologische Exkursions Flora. 7. Verlag. - Verlag Eugen Ulmer, Stuttgart, $1050 \mathrm{pp}$.

Penksza K. \& Szerdahelyi T. (2009): Asteraceae (Compositae) [incl. Ambrosiaceae, Cichoriaceae] Őszirózsafélék családja. - In: KIRÁLY G. (szerk.), Új magyar füvészkönyv. Magyarország hajtásos növényei. Határozókulcsok. - Aggteleki Nemzeti Park Igazgatóság, Jósvafő, pp. 406-466.

PRISZTER Sz. (1998): Növényneveink. A magyar és a tudományos növénynevek szótára. - Mezőgazda Kiadó, Budapest, 547 pp.

PYšEK P., SÁdLO J. \& MANDÁK B. (2002): Catalogue of alien plants of the Czech Republic. - Preslia 74: 97-186.

RBG (2018): The Plant List: Lactuca tatarica (L.) C.A.Mey. - Royal Botanic Gardens, Kew and Missouri Botanic Garden. 2013. http://www.theplantlist.org/tpl1.1/record/gcc-136895 (hozzáférés / accessed: 2018. 08. 08.)

RothMALER W. (1956): Exkursionsflora. Ein Pflanzenbestimmungsbuch für Schulen und Hochschulen. Volk und Wissen Volkseigener Verlag, Berlin, 366 pp.

Rothmaler W., SCHUBert R. \& VENT W. (1986): Exkursionsflora für die Gebiete der DDR und der BRD Band 4. Kritischer Band. - Volk und Wissen Volkseigener Verlag, Berlin, 811 pp.

ROTHMALER W., SCHUBERT R., WERNER K. \& MEUSEL H. (1984): Exkursionsflora für die Gebiete der DDR und der BRD Band 2. Gefäßpflanzen. - Volk und Wissen Volkseigener Verlag, Berlin, 640 pp.

SoJÁK J. (1961): Bemerkungen zu einigen Compositen. - Novit. Bot. Hort. Univ. Carol. Prag. 1961: 33-37.

Tutin T.G., Heywood V.H., Burges N.A., Moore D.M., Valentine D.H., Walters S.M. \& WebB D.A. (1976): Flora Europaea, Vol. 4. - Cambridge University Press, Cambridge, 505 pp.

Tuzson J. (1911): Magyarország fejlődéstörténeti növényföldrajzának főbb vonásai. - Mathematikai és Természettudományi Értesítő 29: 558-589.

Tuzson J. (1913): Adatok a délorosz puszták összehasonlító flórájához. - Botanikai Közlemények 12 (5-6): 181-202.

TzvelEv N.N. (ed.) (2003): Flora of Russia the european part and Bordering regions. Volume VIII. - A.A. Balkema, Rotterdam/Brookfield, $684 \mathrm{pp}$.

WAGENitZ G. (1987): Nachträge, Berichtigungen und Ergänzungen zum Nachdruck der 1. Auflage von Band VI/2 (1928/9). In: HeGI G (ed.), Illustrierte Flora von Mitteleuropa. Spermatophyta Band VI Angiospermae Dicotyledones 4. Teil4. Zweite, überarbeitete und erweiterte Auflage. - Verlag Paul Parey, Berlin/Hamburg, pp. 1353-1483.

Beérkezett / received: 2018. 08. 24. • Elfogadva / accepted: 2018. 10. 31. 